Article

\title{
Expression of Genes Related to Sugar and Amino Acid Transport and Cytokinin Metabolism during Leaf Development and Senescence in Pisum sativum L.
}

\author{
Annu S. Ninan ${ }^{1}$, Jan Grant ${ }^{2}\left[\right.$, Jiancheng Song ${ }^{1,3}$ and Paula E. Jameson ${ }^{1, *}$ (i) \\ 1 School of Biological Sciences, University of Canterbury, Private Bag 4800, Christchurch 8140, New Zealand; \\ annu.ninan@canterbury.ac.nz (A.S.N.); jsong@ytu.edu.cn (J.S.) \\ 2 The New Zealand Institute for Plant \& Food Research Limited, Private Bag 4704, Christchurch 8140, \\ New Zealand; jan.grant@plantandfood.co.nz \\ 3 School of Life Sciences, Yantai University, Yantai 264005, China \\ * Correspondence: paula.jameson@canterbury.ac.nz; Tel.: +64-3-3695181
}

Received: 27 February 2019; Accepted: 19 March 2019; Published: 25 March 2019

check for updates

\begin{abstract}
Gene editing is becoming the plant breeding tool of choice, but prior to targeting a gene for editing, a knowledge of the gene family members (GFMs) controlling yield is required in the specific crop plant. Critical to yield are components from senescing leaves. We targeted genes controlling senescence in Pisum satioum and the release and transport of carbohydrates and amino acids from the source leaves to the pods and seeds. The expression of GFMs for cytokinin biosynthesis (IPT) and destruction $(C K X)$, sucrose transporters (SUT), Sugar Will Eventually be Exported Transporters $(S W E E T)$, amino acid permeases $(A A P)$, and cell wall invertases, was determined using RT-qPCR. GFMs were differentially expressed in leaves of different ages. The expression of many gene family members was lower in the expanding sink leaves compared with the senescing leaves, with the exception of two PsAAP GFMs and $P_{S} C K X 5$, which were highly expressed. Expression of specific PSSWEETs, SUTs, and AAPs increased in the mature and/or senescing leaves. Expression of PSIPTs was least in the mature source leaves, but as strong in the senescing leaves as in the young source leaves. PsCKX7 was expressed in source and senescing leaves. We discuss the potential impact of the targeted reduction of specific PsCKX GFMs on source-sink relationships.
\end{abstract}

Keywords: amino acid transporter $(A A P)$; cytokinin; cytokinin oxidase; isopentenyl transferase; pea; senescence; source-sink; sucrose transporter (SUT); SWEET

\section{Introduction}

For agronomic plants, a critical component that contributes to both yield and nutritional content is the duration of the leaf's life span and its ultimate senescence [1]. During its life span, the typical developing leaf is initially a sink organ-drawing on the resources of the parent plant. During the phase of rapid expansion, the leaf changes to become a source organ, supplying carbohydrate to the plant. Eventually, all leaves undergo senescence. During this process cellular constituents are dismantled, and metabolites are actively recycled and exported from the leaf $[1,2]$. The sink for these metabolites varies depending on the life cycle of the plant. For annual legumes, the pod and developing seeds are the key sink tissues. Legumes have been identified as being of increasing importance in sustainable food production and for human health benefits [3] and, while leaf senescence in Pisum sativum L. (pea) has been described [4], little is known about the expression of the key genes in the pea leaf which co-ordinate the supply of carbohydrate and amino acids to the developing pod and seeds. 
We know from transcriptomic data that the expression of multiple genes changes during the onset and progression of senescence-the so-called senescence associated genes (SAGs) [5-7]. There is a tightly regulated dismantling of intracellular structures (starting with the chloroplasts) in addition to the breakdown of proteins, nucleic acids and lipids, and the mobilisation of sugars and amino acids [8]. The energy required for the progression of senescence is supplied by the continued presence of mitochondria late into the process [9].

Since the 1960s, cytokinins have been implicated in the enhancement of sink activity in leaves [10] and in the delay of senescence [11], with the cytokinin-induced delay of senescence shown to be dependent on the activity of cell wall invertases (CWINV) [12]. The key step in cytokinin biosynthesis is controlled by isopentenyl transferase (IPT), while that of cytokinin degradation is controlled by cytokinin oxidase/dehydrogenase (CKX). Both enzymes are encoded by gene families, including in pea $[13,14]$. Early transcriptomic analyses during the developmental leaf senescence of Arabidopsis thaliana [5] showed decreased expression of an AtIPT and of cytokinin response regulators (RRs) and increased expression of an AtCKX. Others have shown decreases in active forms and increases in inactive forms of endogenous cytokinins in senescing leaves of a variety of species [15-17]. However, after a comprehensive analysis of gene expression and endogenous cytokinins, Edlund et al. [18] suggested that the depletion of cytokinin was unlikely to explain the onset of autumn leaf senescence in aspen, lending support to the statement by Jibran et al. [19] that cytokinin affects the process of senescence but not the regulation of the onset of senescence.

Loading of sugars from source and senescing leaves into the phloem requires the co-ordinated activity of the recently identified Sugar Will Eventually be Exported Transporters (SWEETs) and the sucrose transporters (SUTs) [20,21]. Individual SWEET gene family members (GFMs) have been identified in critical roles for plant development and plant-pathogen interactions [22]. SWEETs belonging to Clades I, II, and IV transport hexoses, while those belonging to Clade III transport sucrose [23-25]. Clade IV SWEETs transport hexoses to the vacuole, while members of Clades I, II, and III transport sugars across the plasma membrane to the apoplast [26]. The activity of SWEETS over the lifetime of a leaf has not been shown for many species. Greater expression of SWEETS in source leaves compared with young sink leaves has been shown for cucumber [25] and for SWEET10 in sweet potato [26], while SAG29—subsequently renamed as Clade III AtSW15—was shown to increase markedly in senescent Arabidopsis leaves [27]. Overexpression of both AtSW15 [27] and of Clade II rice OsSW5 [28] resulted in precocious senescence. Bezrutczyk et al. [29] report impaired phloem loading in maize in which $Z m S W 13 a, b, c$ were knocked out. PsSWEET gene family members have been shown to be expressed in the germinating seedling [30] and to be responsive to both epiphytic and endophytic Rhodococcus fascians [13].

Young expanding leaves are regarded as sinks for nitrogen, with $\mathrm{N}$ transporters effecting uptake of $\mathrm{N}$ into the leaves from the xylem and phloem, whereas mature and senescing leaves are sources of $\mathrm{N}$, utilising transporters to export $\mathrm{N}$ into the phloem for transport to sinks [20]. $\mathrm{N}$ uptake and assimilation has been closely linked to the activity of cytokinins [31,32]. Enhancing endogenous cytokinin has been shown to delay senescence [33-35], as well as the release of $\mathrm{N}$ from senescing leaves [36-38]. As the amino acid permease (AAP) transporters operate on the phloem pathway throughout the plant [20], we monitored the expression of AAP gene family members in pea leaves.

A key breeding target has been identified as the manipulation of source/sink relationships during pod and seed development in legumes [39-42]. Plant breeding using molecular methods is dependent on the knowledge of the differential activity of individual gene family members throughout the plant, particularly if molecular tools such as gene editing are to be utilised. We have shown that family members of transporter and cytokinin biosynthesis and degradation genes express differentially-both spatially and temporally-during the germination of pea seeds [30] and pre- and post-fertilisation in pods and seeds [14], but little is known about the expression of these genes during leaf development and senescence in peas. We targeted those genes controlling senescence and the release and transport of carbohydrates and amino acids from the source leaves to the pods and seeds. 


\section{Results}

We used two popular breeding cultivars of pea, Bolero, a process pea and Bohatyr, a "field" pea as biological replicates to determine which gene family members are consistently expressed despite different breeding histories and growth strategies. Bolero is a "process" pea cultivar with a vining growth habit, with pods harvested immature for both fresh and frozen peas, whereas Bohatyr is a conventional leafed "field" pea, harvested when mature for its protein content as a dried pea. The data are presented as the combined average of the two cultivars, with the data for the individual cultivars shown in supplementary materials.

\subsection{Chlorophyll Analyses}

The chlorophyll content was similar in the expanding sink leaves and the source leaves supporting pods 5 and 20 days after flowering, and thereafter decreased as the leaves began senescing (Figure 1).

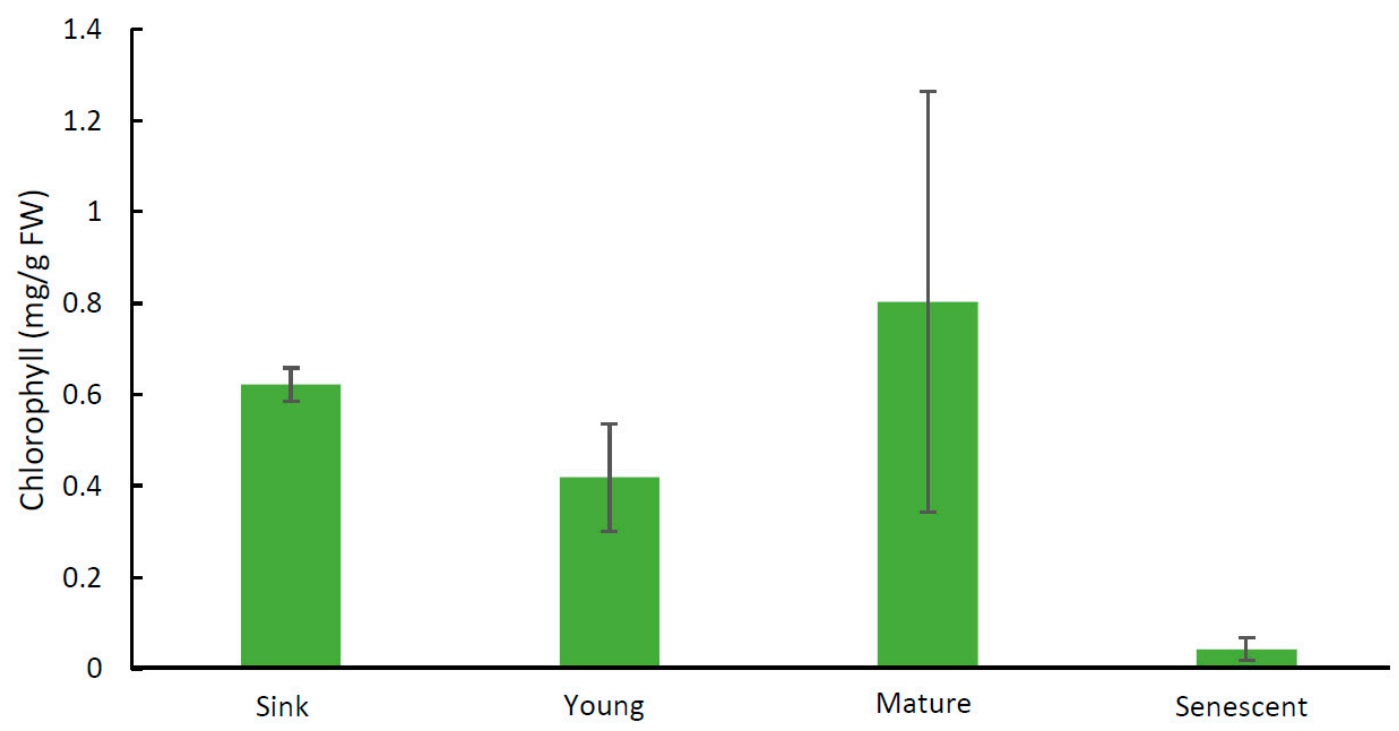

Figure 1. Chlorophyll content of leaves of Pisum sativum. Expanding sink leaves (sink), source leaves subtending pods five days after flowering (young) and 20 days after flowering (mature), and senescing leaves were analysed. Data are the averages of two biological replicates, with three replicate extractions for each sample. Results are \pm s.d.

\subsection{Gene Expression}

Expression data are shown in Figure 2. While there was expression of several Clade I SWEETs in leaves of different ages, there was increased expression of several Clade III SWEETs in the mature and senescing leaves. Expression of PSSUTs 1 and 2 increased as the leaves aged. Expression of the PSCWINVs was generally lowest in the mature and/or senescing leaves.

$P S A A P 6 b$ and $7 b$ showed strong expression in the expanding sink leaves. The majority of the PSAAP gene family members showed the least expression in the young source leaves, while increased expression of several gene family members was detected in the mature source leaves. Many of the PSAAP gene family members were expressed strongly in the senescing leaves, the exception being Cluster 4B PSAAP8, which showed little expression in leaves of any age (data not shown).

The three PSIPT gene family members expressed in the young source leaves showed decreased expression in the mature source leaves but increased expression again in the senescent leaves. A similar pattern was shown for PsCKX expression, but with $P_{S} C K X 5$ expressed in the sink leaves, and PsCKX7 in the source and senescing leaves. 

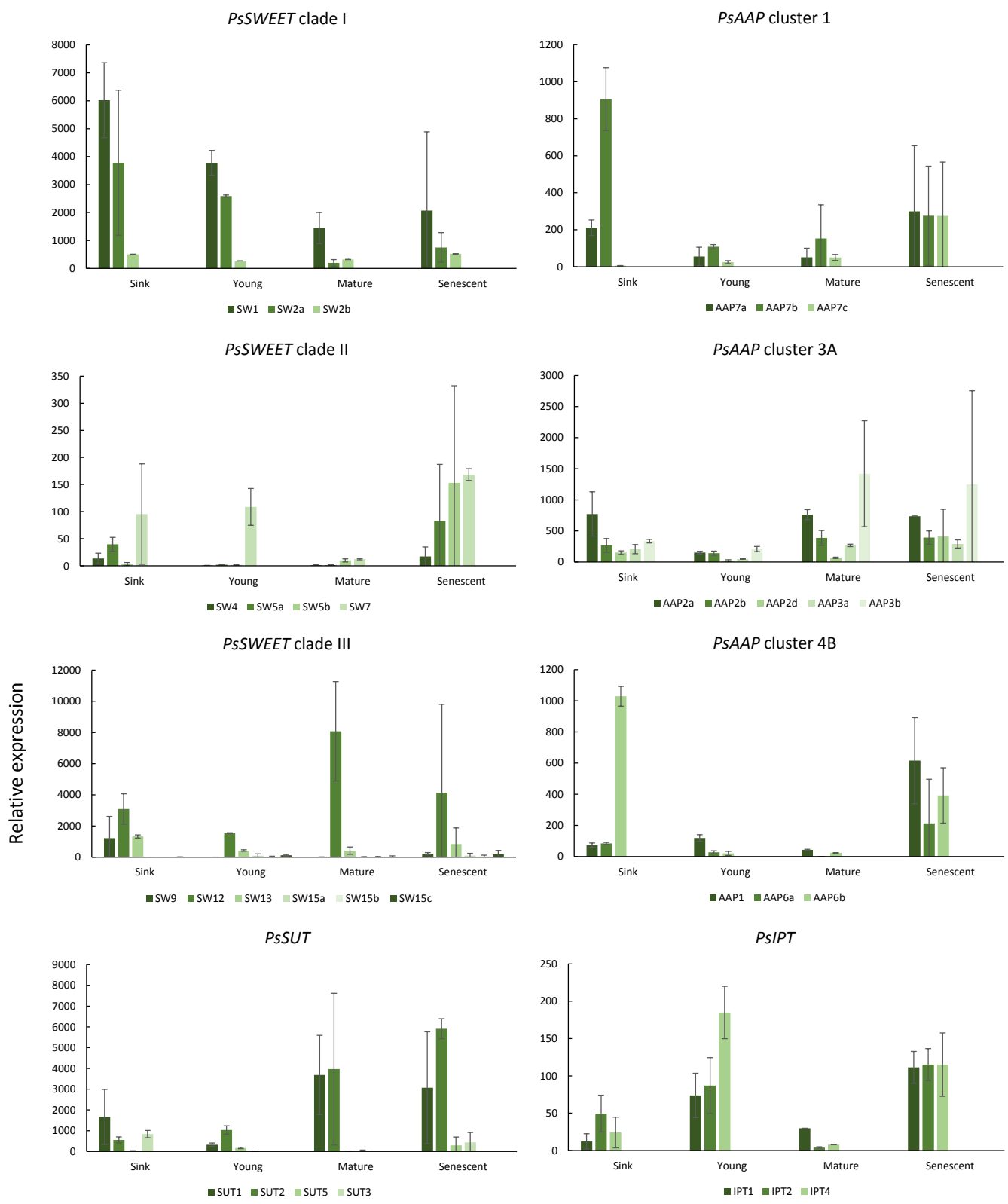

PSCWINV
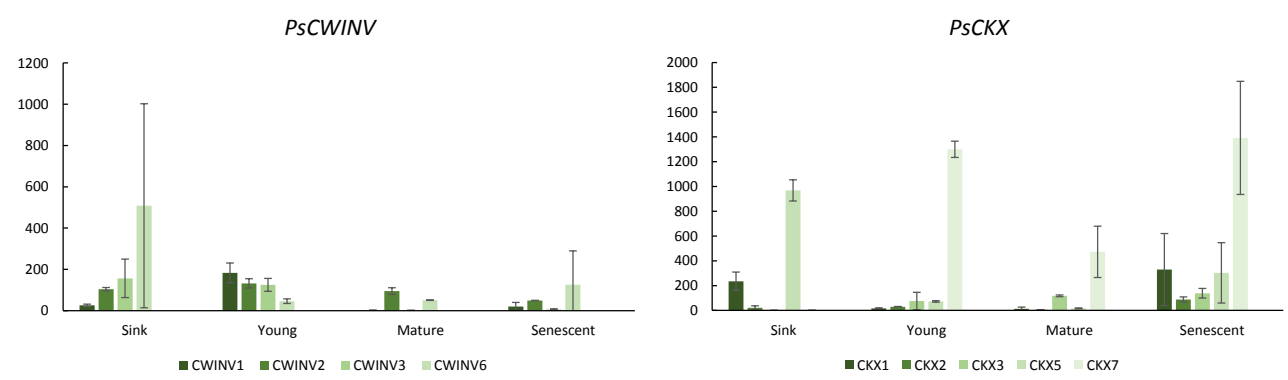

Figure 2. Relative expression of Sugar Will Eventually be Exported Transporter (SWEET), sucrose transporter $(S U T)$, amino acid permease $(A A P)$ transporter gene families, cell wall invertase (CWINV), cytokinin biosynthesis (IPT), and cytokinin degradation (CKX) gene families in leaves of Pisum sativum of different ages (sink: expanding sink leaves; young: source leaves subtending pods five days after flowering; mature: source leaves subtending pods 20 days after flowering; senescent: senescing leaves). Mean fold-change values (y-axis) were calculated using PSEF, PSGAP, and PSACT as internal controls. The results are expressed as the average of two biological replicates, with three technical replicates for each. Results are \pm s.d. 


\section{Discussion}

For translocation through the plant, sucrose must be moved across the plasma membrane to the apoplast and thence into the phloem. In Arabidopsis, Clade III SWEET11 and 12 have been identified as controlling the first step in loading sucrose into the phloem for long-distance transport [24]. Clade III SWEETs load sucrose into the apoplast, from where it is loaded by SUTs into the phloem [22,24]. Previously, an individual SWEET Clade III gene family member (AtSW15; SAG29) was identified as showing increased expression in senescing leaves of Arabidopsis and accelerated senescence in over-expressed lines [27]. In pea, we showed a notable increase in expression in several Clade II and III SWEETs in the senescing leaves. A senescing leaf is offloading its carbohydrate, and the increased expression of the SWEETs was matched by increased expression of PSSUT1 and 2 as the leaves aged. A similar coincidence of expression between SWEETs and SUT transporters occurs in various tissues of Brassica napus L. [21].

PsCWINV family members showed differential expression, as also shown in B. napus leaves [43]. Expression of $P_{S} C W I N V$ s may have led to increased hexoses in the expanding leaves, providing a strong osmoticum to support expansion. Strong expression of specific PsAAP gene family members during leaf expansion is indicative of the import of amino acids into the developing sink leaves [44]. Several $P S A A P$ s were expressed in the mature source and senescing pea leaves. However, the expression of PSAAP8 was not detected (data not shown), even though AtAAP8 has been classified as "the long sought after phloem loader" [45] in Arabidopsis. AAP8 belongs to Cluster 4B, the cluster that PsAAP1 and 6 are allocated to. However, we showed that it is members of Cluster $3 A$ which were most highly expressed in the mature source leaves of pea. Not surprisingly, the PsAAPs were strongly expressed in the senescing leaves, as these AAPs aid in the export of the degraded protein as the leaf senesces [8]. Moreover, during pea leaf senescence the transport of amino acids was not delegated to any specific cluster. Similar patterns are seen also for B. napus AAP gene family members [43,46].

Low expression of PSIPT gene family members in the sink leaves was not unexpected, and has been shown in both brassicas [43,47] and cereals [48]. Xylem-supplied cytokinin moves readily with the transpiration stream and accumulates in sink leaves [49], indicating that root-supplied cytokinin potentially provides all necessary cytokinin to the expanding sink [50]. The decrease in PSIPT expression in the mature source leaves during pod filling is not surprising either, as the release of nutrients is required, rather than a cytokinin-enhanced sink activity [10]. According to the data from Buchanan-Wollaston et al. [5], an increase in expression of PSIPT in senescing leaves would not have been expected, although an increase has been reported before in both rapid cycling Brassica rapa [51], and forage brassica B. napus [43], and an increase in the cytokinin-activating gene, LOG7a, was detected in senescing aspen leaves [18]. Additionally, both van der Graff et al. [6] and Edlund et al. [18] showed upregulation of specific cytokinin response regulators in senescing leaves of Arabidopsis and aspen, respectively. However, in pea, there appears to be tight regulation of any additional cytokinin (either arriving via the xylem or newly biosynthesized), as increased activity of PSCKX5 occurred in the sink leaves, and increased expression of $P_{S} C K X 7$ occurred in the maturing and senescing leaves. Interestingly, CKX7 was also specifically upregulated in senescing aspen leaves [18], as were several $B n C K X$ gene family members [43].

It is possible that the role of cytokinins as scavengers of reactive oxygen species (ROS) is required in senescing leaves. Cytokinin can enhance the activities of anti-oxidant enzymes such as catalase, superoxide dismutase, peroxidase, and ascorbate peroxidase [52-56]. Reactive oxygen species are produced both in the chloroplast [53] and in the mitochondria [57] and can be damaging to membrane integrity [55]. We suggest that cytokinin may be required to assist the maintenance of mitochondrial integrity until the very final stages of senescence through the activation of leaf anti-oxidant activities. Besides providing energy during leaf senescence, the mitochondria play a key role in nitrogen remobilisation [9]. However, any role for cytokinin during the active phase of senescence is likely to be complex $[6,18]$. 
$P_{s} C K X 7$ was expressed in the young, mature, and senescing leaves. $P_{s} C K X 7$ was also expressed in the meristem of peas, in the pea ovule one day before fertilisation [14], and during early shoot and root growth of pea seedlings [30]. A deficiency in cytokinin has been suggested as a causal factor in limiting the pod number in legumes [58], and the downregulation of $P_{S} C K X 7$ in the shoot meristem has been suggested as a target for gene editing, or for Targeted Induced Loci Lesions IN Genomes (TILLING) [14]. Downregulation of PsCKX7 may also lead to increased cytokinin in the shoots, roots, and leaves. Modestly increased endogenous cytokinin has been shown to enhance stress tolerance [35]. Pea yield is reported to be affected by stress and particularly by high temperatures [59]. Savada et al. [60] suggest that the effect of heat stress may be through ethylene biosynthesis and signalling. As there is a complex interaction between cytokinin and the perception and/or biosynthesis of ethylene [61], enhancing stress tolerance in pea-particularly at the time of pollination and fruit set-via elevated levels of cytokinin would need to be carefully evaluated. Delayed leaf senescence may be another consequence of the downregulation of $P_{S} C K X 7$. Whether this is beneficial to the yield and protein content of seeds will depend on the resulting strength of the mature and senescing leaves in retaining metabolites [36].

In summary, detailed knowledge of the temporal specificity of gene family members within cultivars of a species is not only useful but required before being able to target specific transporter or cytokinin gene family member(s) for gene editing in order to avoid unintended effects.

\section{Materials and Methods}

\subsection{Plant Material}

Seeds of P. sativum L. cv. Bolero (a process pea) and cv. Bohatyr (a field pea) were sourced from The New Zealand Institute for Plant \& Food Research. Both cultivars represent the industry standard and are pure lines. Twenty-two seeds of each line were sown (planted) during summer (December, Christchurch, New Zealand). Each seed was sown in a pot containing potting mix, mixed with fertilizers. Growth room conditions were $22^{\circ} \mathrm{C}$ during the $16 \mathrm{~h}$ day and $14{ }^{\circ} \mathrm{C}$ during the $8 \mathrm{~h}$ night. Plants were watered every two days to keep the plants moist but not wet. Plants were fertilised two or three times during the growing period. Flowers were tagged just as the standard petal opened.

Plant material for gene expression and chlorophyll analysis was obtained from pooled samples of individual leaves collected from five cv. Bolero and five cv. Bohatyr plants. The leaf samples collected were young expanding sink leaves, source leaves, and senescent leaves. Two sets of source leaves were collected: those supporting pods five days after flowering (DAF) and those supporting pods 20 DAF. Both types of leaves were fully expanded, but those associated with pods 5 DAF are here referred to as "young source leaves" and those collected when pods were 20 DAF are referred to as "mature source leaves". Leaf samples were collected into $15 \mathrm{~mL}$ falcon tubes, immediately frozen in liquid nitrogen, and stored at $-80^{\circ} \mathrm{C}$.

\subsection{Gene Isolation and Sequence Analysis}

Sequences of family members from candidate genes of interest were isolated from an RNA-Seq transcriptome as described in Dhandapani et al. [13]. A pool of total RNA samples extracted separately from multiple developmental stages of leaves, flowers, and siliques was used to construct the cDNA library, which was then sequenced using an Illumina HiSeq2000 genome analyser at the Beijing Genomic Institute (BGI) customer service. Orthologue sequences of IPT, CKX, SUT, AAP, CWINV, and SWEET from legume species available in the GenBank database were used as query sequences to BLAST search our P. sativum transcriptome using prfectBLAST 2.0. The putative sequences were verified via BLAST searching the GenBank database and multiple sequence alignment with representative orthologue sequences in closely related species [13]. 


\subsection{RNA Isolation and $c D N A$ Synthesis}

Total RNA was extracted from up to $100 \mathrm{mg}$ of frozen samples using TRIzol Reagent (Invitrogen, Carlsbad, CA, USA) following the manufacturer's instructions and immediately stored at $-20{ }^{\circ} \mathrm{C}$. The integrity and quality of isolated RNA was assessed by running $1 \mu \mathrm{L}$ samples on a $1 \%(\mathrm{w} / \mathrm{v})$ agarose gel. The concentration and purity of the total RNA was assessed using a Nanodrop ${ }^{\mathrm{TM}}$ spectrophotometer. Extracted RNA was converted to cDNA through reverse transcription. Approximately $1 \mu \mathrm{g}$ of total RNA, 50U Expand Reverse Transcriptase (Roche, Mannheim, Germany), 50 pmol oligo (dT) primers and 100 pmol random hexamer (pdN6) primers were used in a $20 \mu \mathrm{L}$ reaction. The final reaction mix was incubated at $42{ }^{\circ} \mathrm{C}$ for $2 \mathrm{~h}$, and then at $70{ }^{\circ} \mathrm{C}$ for $15 \mathrm{~min}$ to deactivate the enzyme. The cDNA was diluted 10 -fold with nanopure water and stored at $-20^{\circ} \mathrm{C}$.

\subsection{Quantitative Reverse Transcription Polymerase Chain Reaction}

Quantitative RT-PCR was used to measure relative gene expression of the individual family members across the various plant tissues as they developed. Specific PCR primers were designed for each family member of the five genes of interest. A volume of $15 \mu \mathrm{L}$ was used for all qPCR reactions in a Rotor-Gene Q (Qiagen) real-time PCR instrument, using home-made SYBR Green master mix or a KAPA SYBR ${ }^{\circledR}$ FAST qPCR Kit (Kapa Biosystems, Boston, USA). Three reference genes, elongation factor $(E F)$, actin $(A C T)$ and $G A P D H$, were used as internal controls to normalise the data by correcting for differences in the quantity of cDNA used as templates, as described previously $[13,14,62]$. The relative expression (fold change) of each target gene was then calculated using the $2^{-\Delta \Delta} C_{t}$ method [63] using a constant $\Delta C_{t}$ of 30 minus the average correction factor derived from the reference genes as the value against which all samples were calculated. Three technical replicates for each of the two biological replicates (Bolero and Bohatyr) were carried out for each sample set.

\subsection{Chlorophyll Estimation}

Chlorophyll from three sub-samples of the pooled leaves for each developmental stage was extracted into DMF and analysed using a Nanodrop spectrophotometer as described in Evans et al. [64]. The total chlorophyll content was calculated using the equation of Wellburn [65]: $\mathrm{Ch}_{\text {total }}=7 \cdot 12 A_{664}+18 \cdot 12 A_{647}$.

Supplementary Materials: The following are available online at http://www.mdpi.com/2223-7747/8/3/76/s1, Figure S1: Chlorophyll content of leaves of Pisum sativum cvs. Bolero and Bohatyr. Figure S2: Relative expression of PSSWEET, SUT and AAP transporter gene families, CWINV, cytokinin biosynthesis (IPT) and cytokinin degradation $(C K X)$ gene families in leaves of Pisum sativum cv. Bolero of different ages. Figure S3: Relative expression of PSSWEET, SUT, and AAP transporter gene families, CWINV, cytokinin biosynthesis (IPT) and cytokinin degradation (CKX) gene families in leaves of Pisum sativum cv Bohatyr of different ages.

Author Contributions: Conceptualization, P.E.J., J.S., J.G.; methodology, J.S., P.E.J., validation, A.S.N.; formal analysis, A.S.N.; investigation, A.S.N.; resources, P.E.J., J.S., J.G.; data curation, A.S.N., J.S.; visualization, A.S.N., writing—original draft preparation, P.E.J.; writing—review and editing, P.E.J., A.S.N., J.S., J.G.; supervision, P.E.J., J.S., J.G.; project administration, P.E.J.; funding acquisition, P.E.J., J.G., J.S.

Funding: This research was funded from the FRST/MBIE 'Advanced Seed Production Systems' grant to P.E.J., J.S. and J.G. grant number LINX0803. A.S.N was in receipt of a scholarship from the University of Canterbury, Christchurch, New Zealand.

Acknowledgments: Thanks to John Clemens for assistance with the graphs.

Conflicts of Interest: The authors declare no conflict of interest. The funders had no role in the design of the study; in the collection, analyses, or interpretation of data; in the writing of the manuscript, or in the decision to publish the results. 


\section{References}

1. Woo, H.R.; Masclaux-Daubresse, C.; Lim, P.O. Plant senescence: How plants know when and how to die. J. Exp. Bot. 2018, 69, 715-718. [CrossRef]

2. Buchanan-Wollaston, V.; Earl, S.; Harrison, E.; Mathas, E.; Navabpour, S.; Page, T.; Pink, D. The molecular analysis of leaf senescence-A genomics approach. Plant Biol. J. 2003, 1, 3-22.

3. Foyer, C.H.; Lam, H.-M.; Nguyen, H.T.; Siddique, K.H.M.; Varshney, R.K.; Colmer, T.D.; Cowling, W.; Bramley, H.; Mori, T.A.; Hodgson, J.M.; et al. Neglecting legumes has compromised human health and sustainable food production. Nat. Plant 2016, 2, 16112.

4. Vanacker, H.; Sandalio, L.M.; Jiménez, A.; Palma, J.M.; Corpas, F.J.; Meseguer, V.; Gómez, M.; Sevilla, F.; Leterrier, M.; Foyer, C.H.; et al. Roles for redox regulation in leaf senescence of pea plants grown on different sources of nitrogen nutrition. J. Exp. Bot. 2006, 57, 1735-1745. [CrossRef]

5. Buchanan-Wollaston, V.; Page, T.; Harrison, E.; Breeze, E.; Lim, P.O.; Nam, H.G.; Lin, J.-F.; Wu, S.-H.; Swidzinski, J.; Ishizaki, K.; et al. Comparative transcriptome analysis reveals significant differences in gene expression and signalling pathways between developmental and dark/starvation-induced senescence in Arabidopsis. Plant J. 2005, 42, 567-585. [CrossRef]

6. $\quad$ van der Graaff, E.; Schwacke, R.; Schneider, A.; Desimone, M.; Flügge, U.-I.; Kunze, R. Transcription analysis of Arabidopsis membrane transporters and hormone pathways during developmental and induced leaf senescence. Plant Physiol. 2006, 141, 776-792. [CrossRef]

7. Sade, N.; del Mar Rubio-Wihelmi, M.; Umnajkitikorn, K.; Blumwald, E. Stress-induced senescence and plant tolerance to abiotic stress. J. Exp. Bot. 2018, 69, 845-853. [CrossRef]

8. Clément, G.; Moison, M.; Soulay, F.; Reisdorf-Cren, M.; Masclaux-Daubresse, C. Metabolomics of laminae and midvein during leaf senescence and source-sink metabolite management in Brassica napus L. leaves. J. Exp. Bot. 2018, 69, 891-903. [CrossRef]

9. Chrobok, D.; Law, S.R.; Brouwer, B.; Lindén, P.; Ziolkowska, A.; Liebsch, D.; Narsai, R.; Szal, B.; Moritz, T.; Rouchier, N.; et al. Dissecting the metabolic role of mitochondria during developmental leaf senescence. Plant Physiol. 2016, 172, 2132-2153. [CrossRef]

10. Mothes, K.; Engelbrecht, L. On the activity of a kinetin-like root factor. Life Sci. 1963, 11, 852-857. [CrossRef]

11. Richmond, A.E.; Lang, A. Effect of kinetin on protein content and survival of detached Xanthium leaves. Science 1957, 125, 650-651. [CrossRef]

12. Balibrea, L.M.E.; Gonzalez, M.C.G.; Fatima, T.; Ehneß, R.; Lee, T.; Proels, R.; Tanner, W.; Roitsch, R. Extracellular invertase is an essential component of cytokinin-mediated delay of senescence. Plant Cell 2004, 16, 1276-1287. [CrossRef]

13. Dhandapani, P.; Song, J.; Novak, O.; Jameson, P.E. Infection by Rhodococcus fascians maintains cotyledons as a sink tissue for the pathogen. Ann. Bot. 2017, 119, 841-852.

14. Ninan, A.S.; Shah, A.; Song, J.; Jameson, P.E. Differential gene expression in the meristem and during early fruit growth of Pisum sativum L. identifies potential targets for breeding. Int. J. Mol. Sci. 2017, $18,428$. [CrossRef]

15. Jameson, P.E. Cytokinin metabolism and compartmentation. In Cytokinins Chemistry, Activity and Function; Mok, D.W.S., Mok, M.C., Eds.; CRC Press: Boca Raton, FL, USA, 1994; pp. 113-128.

16. Šmehilová, M.; Dobrůšková, J.; Novák, P.; Takáč, T.; Galuszka, P. Cytokinin-specific glycosyltransferases possess different roles in cytokinin homeostasis maintenance. Front. Plant Sci. 2016, 7, 1264. [CrossRef]

17. Brütting, C.; Schäfer, M.; Vanková, R.; Gase, K.; Baldwin, I.T.; Meldau, S. Changes in cytokinins are sufficient to alter developmental patterns of defense metabolites in Nicotiana attenuata. Plant J. 2017, 89, 15-30. [CrossRef]

18. Edlund, E.; Novak, O.; Karady, M.; Ljung, K.; Jansson, S. Contrasting patterns of cytokinins between years in senescing aspen leaves. Plant Cell Environ. 2017, 40, 622-634. [CrossRef]

19. Jibran, R.; Hunter, D.A.; Dijkwel, P.P. Hormonal regulation of leaf senescence through integration of developmental and stress signals. Plant Mol. Biol. 2013, 82, 547-561. [CrossRef]

20. Yadav, U.P.; Ayre, B.G.; Bush, R. Transgenic approaches to altering carbon and nitrogen partitioning in whole plants: Assessing the potential to improve crop yields and nutritional quality. Front. Plant Sci. 2015, 6, 275. [CrossRef] 
21. Jian, H.; Lu, K.; Yang, B.; Wang, T.; Zhang, L.; Zhang, A.; Wang, J.; Liu, L.; Qu, C.; Li, J. Genome-wide analysis and expression profiling of the SUC and SWEET gene families of sucrose transporters in oilseed rape (Brassica napus L.). Front. Plant Sci. 2016, 7, 1464. [CrossRef]

22. Chandran, D. Co-option of developmentally regulated plant SWEET transporters for pathogen nutrition and abiotic stress tolerance. Int. J. Biochem. Mol. Biol. 2015, 67, 461-471. [CrossRef]

23. Chen, L.-Q.; Hou, B.-H.; Lalonde, S.; Takanaga, H.; Hartung, M.L.; Qu, X.-Q.; Guo, W.-J.; Kim, J.-G.; Underwood, W.; Chaudhuri, B.; et al. Sugar transporters for intercellular exchange and nutrition of pathogens. Nature 2010, 468, 527-534. [CrossRef]

24. Chen, L.-Q.; Qu, X.-Q.; Hou, B.-H.; Sosso, D.; Osorio, S.; Fernie, A.R.; Frommer, W.B. Sucrose efflux mediated by SWEET proteins as a key step for phloem transport. Science 2012, 335, 207-211. [CrossRef]

25. Li, Y.; Feng, S.; Ma, S.; Sui, X.; Zhang, Z. Spatiotemporal expression and substrate specificity analysis of the cucumber SWEET gene family. Front. Plant Sci. 2017, 8, 1855. [CrossRef]

26. Li, Y.; Wang, Y.; Zhang, H.; Zhang, Q.; Zhai, H.; Liu, Q.; He, S. The plasma membrane-localized sucrose transporter IbSWEET10 contributes to the resistance of sweet potato to Fusarium oxysporum. Front. Plant Sci. 2017, 8, 197. [CrossRef]

27. Seo, P.J.; Park, J.-M.; Ki Kang, S.; Kim, S.-G.; Park, C.-M. An Arabidopsis senescence-associated protein SAG29 regulates cell viability under high salinity. Planta 2011, 233, 189-200. [CrossRef]

28. Zhou, Y.; Liu, L.; Huang, W.; Yuan, M.; Zhou, F.; Li, X.; Lin, Y. Overexpression of OsSWEET5 in rice causes growth retardation and precocious senescence. PLoS ONE 2014, 9, e94210. [CrossRef]

29. Bezrutczyk, M.; Hartwig, T.; Horschman, M.; Nian Char, S.; Yang, J.; Yang, B.; Frommer, W.B.; Sosso, D. Impaired phloem loading in zmsweet $13 a, b, c$ sucrose transporter triple knock-out mutants in Zea mays. New Phytol. 2018, 218, 594-603. [CrossRef]

30. Jameson, P.E.; Dhandapani, P.; Novak, O.; Song, J. Cytokinins and expression of SWEET, SUT, SWINV and AAP genes increase as pea seeds germinate. Int. J. Mol. Sci. 2016, 17, 2013. [CrossRef]

31. Guo, Q.; Turnbull, M.H.; Song, J.; Roche, J.; Novak, O.; Späth, J.; Jameson, P.E.; Love, J. Depletion of carbohydrate reserves limits nitrate uptake during early regrowth in Lolium perenne L. J. Exp. Bot. 2017, 68, 1569-1583. [CrossRef]

32. Gu, J.; Li, Z.; Mao, Y.; Struik, P.C.; Zhang, H.; Liu, L.; Wang, Z.; Yang, J. Roles of nitrogen and cytokinin signals in root and shoot communications in maximizing of plant productivity and their agronomic applications. Plant Sci. 2018, 274, 320-331. [CrossRef]

33. McKenzie, M.J.; Mett, V.; Reynolds, P.H.S.; Jameson, P.E. Controlled cytokinin production in transgenic tobacco using a copper-inducible promoter. Plant Physiol. 1998, 116, 969-977. [CrossRef]

34. Gan, S.; Amasino, R.M. Inhibition of leaf senescence by autoregulated production of cytokinin. Science 2014, 270, 1986-1988. [CrossRef]

35. Guo, Y.; Gan, S. Translational researches of leaf senescence for enhancing plant productivity and quality. J. Exp. Bot. 2014, 65, 3901-3913. [CrossRef]

36. Jordi, W.; Schapendonk, A.; Davelaar, E.; Stoopen, G.M.; Pot, C.S.; de Visser, R.; van Rhijn, J.A.; Gan, S.; Amasino, R.M. Increased cytokinin levels in transgenic $P_{S A G} 12-I P T$ tobacco plants have large direct and indirect effects on leaf senescence, photosynthesis and N partitioning. Plant Cell Environ. 2000, 23, 279-289. [CrossRef]

37. Cowan, A.K.; Freeman, M.; Björkman, P.-O.; Nicander, B.; Sitbon, F.; Tillberg, E. Effects of senescence-induced alteration in cytokinin metabolism on source-sink relationships and ontogenic and stress-induced transitions in tobacco. Planta 2005, 221, 801-814. [CrossRef]

38. Criado, M.V.; Caputo, C.; Roberts, I.N.; Castro, M.A.; Barneix, A.J. Cytokinin-induced changes of nitrogen remobilization and chloroplast ultrastructure in wheat (Triticum aestivum). J. Plant Physiol. 2009, 166, 1775-1785. [CrossRef]

39. Rosche, E.; Blackmore, D.; Tegeder, M.; Richardson, T.; Schroeder, H.; Higgins, T.J.V.; Frommer, W.B.; Offler, C.E.; Patrick, J.W. Seed-specific overexpression of a potato sucrose transporter increases sucrose uptake and growth rates of developing pea cotyledons. Plant J. 2002, 30, 165-175. [CrossRef]

40. Rolletschek, H.; Hosein, F.; Miranda, M.; Heim, U.; Götz, K.-P.; Schlereth, A.; Borisjuk, L.; Saalbach, I.; Wobus, U.; Weber, H. Ectopic expression of an amino acid transporter (VfAAP1) in seeds of Vicia narbonensis and pea increases storage proteins. Plant Physiol. 2005, 137, 1236-1249. [CrossRef] 
41. Tegeder, M. Transporters involved in source to sink partitioning of amino acids and ureides: Opportunities for crop improvement. J. Exp. Bot. 2014, 65, 1865-1878. [CrossRef]

42. Tegeder, M.; Masclaux-Daubresse, C. Source and sink mechanisms of nitrogen transport and use. New Phytol. 2017, 217, 35-53.

43. Song, J.; Jiang, L.; Jameson, P.E. Expression patterns of Brassica napus genes implicate IPT, CKX, sucrose transporter, cell wall invertase, and amino acid permease gene family members in leaf, flower, silique, and seed development. J. Exp. Bot. 2015, 66, 5067-5082.

44. Rentsch, D.; Hirner, B.; Schmelzer, E.; Frommer, W.B. Salt stress-induced proline transporters and salt stress-repressed broad specificity amino acid permeases identified by suppression of a yeast amino acid permease-targeting mutant. Plant Cell 1996, 8, 1437-1446. [CrossRef]

45. Santiago, J.P.; Tegeder, M. Connecting source with sink: The role of Arabidopsis AAP8 in phloem loading of amino acids. Plant Physiol. 2016, 171, 508-521. [CrossRef]

46. Tilsner, J.; Kassner, N.; Struck, C.; Lohaus, G. Amino acid contents and transport in oilseed rape (Brassica napus L.) under different nitrogen conditions. Planta 2005, 221, 328-338. [CrossRef]

47. Liu, Z.; Lv, Y.; Zhang, M.; Liu, Y.; Kong, L.; Zou, M.; Lu, G.C.J.; Yu, X. Identification, expression and comparative genomic analysis of the IPT and CKX gene families in Chinese cabbage (Brassica rapa ssp. pekinensis). BMC Genom. 2013, 14, 594. [CrossRef]

48. Vyroubalová, S.; Václaviková, K.; Turečková, V.; Novák, O.; Šmehilová, M.; Hluska, T.; Ohnoutková, L.; Frébort, I.; Galuszka, P. Characterization of new maize genes putatively involved in cytokinin metabolism and their expression during osmotic stress in relation to cytokinin levels. Plant Physiol. 2009, 151, 433-447. [CrossRef]

49. Jameson, P.E.; Letham, D.S.; Zhang, R.; Parker, C.W.; Badenoch-Jones, J. Cytokinin translocation and metabolism in lupin species. I. Zeatin riboside introduced into the xylem at the base of Lupinus angustifolius stems. Aust. J. Plant Physiol. 1987, 14, 695-718. [CrossRef]

50. Hirose, N.; Takei, K.; Huroha, T.; Kamada-Nobusada, T.; Hayashi, H.; Sakakibara, H. Regulation of cytokinin biosynthesis, compartmentalization and translocation. J. Exp. Bot. 2008, 59, 75-83. [CrossRef]

51. O'Keefe, D.; Song, J.; Jameson, P.E. Isopentenyl transferase and cytokinin oxidase/dehydrogenase gene family members are differentially expressed during pod and seed development in rapid-cycling brassica. J. Plant Growth Regul. 2011, 30, 92-99. [CrossRef]

52. Clarke, S.R.; Guy, P.L.; Burritt, D.J.; Jameson, P.E. Changes in the activities of antioxidant enzymes in response to virus infection and hormone treatment. Physiol. Plant 2002, 114, 157-164. [CrossRef]

53. Zavaleta-Mancera, H.A.; López-Delgado, H.; Loza-Tavera, H.; Mora-Herrera, M.; Trevilla-García, C.; Vargas-Suárez, M.; Ougham, H. Cytokinin promotes catalase and ascorbate peroxidase activities and preserves the chloroplast integrity during dark-senescence. J. Plant Physiol. 2007, 164, 1572-1582. [CrossRef]

54. Merewitz, E.B.; Du, H.; Yu, W.; Liu, Y.; Gianfagna, T.; Huang, B. Elevated cytokinin content in ipt transgenic creeping bentgrass promotes drought tolerance through regulating metabolite accumulation. J. Exp. Bot. 2012, 63, 1315-1328. [CrossRef]

55. Huang, J.; Han, B.; Xu, S.; Zhou, M.; Shen, W. Heme oxygenase-1 is involved in the cytokinin-induced alleviation of senescence in detached wheat leaves during dark incubation. J. Plant Physiol. 2011, 168, 768-775.

56. Xu, Y.; Burgess, P.; Zhang, Z.; Huang, B. Enhancing cytokinin synthesis by overexpressing ipt alleviated drought inhibition of root growth through activating ROS-scavenging systems in Agrostis stolonifera. J. Exp. Bot. 2016, 67, 1979-1992. [CrossRef]

57. Zimmerman, P.; Zentgraf, U. The correlation between oxidative stress and leaf senescence during plant development. Cell. Mol. Biol. Lett. 2005, 10, 515-534.

58. Jameson, P.E.; Song, J. Cytokinin: A key driver of seed yield. J. Exp. Bot. 2016, 67, 593-606. [CrossRef]

59. Ozga, J.A.; Kaur, H.; Savada, R.P.; Reinecke, D.M. Hormonal regulation of reproductive growth under normal and heat-stress conditions in legume and other model crop species. J. Exp. Bot. 2017, 68, 1885-1894. [CrossRef]

60. Savada, R.P.; Ozga, J.A.; Jayasinghege, C.P.A.; Waduthanthri, K.D.; Reinecke, D.M. Heat stress differentially modifies ethylene biosynthesis and signalling in pea floral and fruit tissues. Plant Mol. Biol. 2017, 95, 313-331. [CrossRef] 
61. Gapper, N.E.; Coupe, S.A.; McKenzie, M.A.; Sinclair, B.K.; Lill, R.E.; Jameson, P.E. Regulation of harvest-induced senescence in broccoli (Brassica oleracea var. italica) by cytokinin, ethylene, and sucrose. J. Plant Growth Regul. 2005, 24, 153-165. [CrossRef]

62. Song, J.; Jiang, L.; Jameson, P.E. Co-ordinate regulation of gene family members during flag leaf and reproductive development in wheat. BMC Plant Biol. 2012, 12, 78.

63. Pfaffl, M.W. A new mathematical model for relative quantification in real-time RT-PCR. Nucl. Acid Res. 2001, 29, e45. [CrossRef]

64. Evans, T.; Song, J.; Jameson, P.E. Micro-scale chlorophyll analysis and developmental expression of a cytokinin oxidase/dehydrogenase gene during leaf development and senescence. Plant Growth Regul. 2012, 66, 95-99. [CrossRef]

65. Wellburn, A.R. The spectral determination of chlorophylls a and $b$, as well as total carotenoids, using various solvents with spectrophotometers of different resolution. J. Plant Physiol. 1994, 144, 307-313. [CrossRef]

C 2019 by the authors. Licensee MDPI, Basel, Switzerland. This article is an open access article distributed under the terms and conditions of the Creative Commons Attribution (CC BY) license (http:/ / creativecommons.org/licenses/by/4.0/). 